\title{
TO LEND OR TO BORROW ON THE INTERBANK MARKET: WHAT MATTERS FOR COMMERCIAL BANKS IN THE VISEGRAD COUNTRIES
}

\section{Pavla Vodová*}

\begin{abstract}
:
The aim of this paper is to find out determinants which affect the commercial banks' decision to lend on the interbank market in the Visegrad countries. The data cover the period from 2000 to 2011. The net interbank position of individual banking sectors significantly differs. Results of the probit model showed that banks' decision to lend in interbank market is determined both by bank-specific and macroeconomic factors. Bank liquidity, capital adequacy and quality of the loan portfolio are important bank-specific factors. Growth rate of the gross domestic products, unemployment rate, financial crisis and level of interest rates matter among macroeconomic factors. Although the Visegrad countries have a lot in common, different factors determined the banks' decision in individual countries. Moreover, the direction of influence of some factors may also differ.
\end{abstract}

Keywords: interbank market, probit model, commercial banks, Visegrad countries, liquidity risk, liquidity hoarding

JEL Classification: C25, G01, G21

\section{Introduction}

Banks transform liquid short-term liabilities into illiquid long-term assets. Because of this maturity transformation, banks are exposed to a liquidity risk. Each bank must have sufficient liquidity. This can be maintained by holding a sufficient buffer of liquid assets or by a loan from other banks on the interbank market. The importance of liquidity risk has been very significantly revised during the global financial crisis. As a result of a continued drop in the market value of mortgage-backed securities from the subprime segment of the US market and the announcement of problems of some European banks, the interbank market came under extreme strain. This confidence crisis had the following consequences: interbank interest rates sharply rose; many segments of the structured credit and mortgage market ceased to trade at all making it difficult to price outstanding positions. In some cases, banks failed to raise enough cash through asset sales. As a result of liquidity hoarding of some banks, interbank lending become very difficult and for some banks even impossible (Ewerhart and Valla, 2008). In response to the freezing up of the interbank market, the European Central Bank, the U.S. Federal Reserve and national central banks

* Pavla Vodová, Silesian University, School of Business Administration, Karviná, Czech Republic (vodova@opf.slu.cz).

This paper was prepared with financial support of the Czech Science Foundation (Project GAČR No. P403/11/P243: Liquidity Risk of Commercial Banks in the Visegrad Countries). I would like to thank the two anonymous reviewers for their helpful and valuable comments and suggestions to improve the quality of the paper. 
respond (Černohorský et al., 2010). Even with extensive liquidity supports, a number of banks failed, and they were forced into mergers or required resolution (BIS, 2009). Systemic risk of the global banking system has been analyzed by Klinger and Teplý (2013).

As a well functioning interbank market is essential for efficient financial intermediation, it is evident that bank liquidity and smooth functioning of interbank markets should be of crucial importance for academicians and policymakers. However, the literature investigates mainly the risk of contagion through the interbank market (e.g. Allen and Gale, 2000; Blavarg and Nimander, 2002; Memmel and Sachs, 2013; or Wells, 2004). Only Lucchetta (2007) analyzed the factors which influence the behaviour of banks on the interbank market. The aim of this paper is therefore to find out determinants which affect the commercial banks' decisions to lend on the interbank market in the Visegrad countries. We will focus also on the development of the net position of commercial banks on the interbank markets.

There are several reasons why we focus on Visegrad countries. The Visegrad Group is an association of countries that positively cope with the consequences of the communist era, and gradually become a respected group in an international political scene. In these countries, the financial system can be characterized as bank-oriented. Banks have a dominant role in financial intermediation and they are also important for the whole economy of these countries. All Visegrad countries are characterized by a universal banking model. The group of analyzed countries is sufficiently homogenous because of the cooperation within the Visegrad countries and the nature of all four banking sectors. However, since the activities of banks in each country slightly differ, we can expect some differences also in liquidity risk management, determinants of bank liquidity and vulnerability of banks to potential liquidity shocks. Various studies investigated various aspects of the functioning of stock markets (Stavárek and Heryán, 2012), exchange rates (Stavárek, 2010), bank concentration, competition and efficiency (Řepková and Stavárek, 2011), credit crisis (Lawson and Zimková, 2009) and financial integration (Matoušek and Stavárek, 2012; Vodová, 2012) in the Visegrad countries. Teplý et al. (2012) and Černohorská et al. (2012) analyzed market liquidity risk in Slovakia. However, the empirical evidence of banks' behaviour on the interbank market is still missing (Vodová 2013, provided the only complex study of determinants of bank liquidity in these countries). This paper therefore fills this gap.

The paper is structured as follows. The next section defines bank liquidity and its link to the interbank market. Section 3 describes trends in positions of banks on the interbank market in the Visegrad countries. Following sections focus on the model and show results of a probit model analysis. The last section captures concluding remarks.

\section{Bank Liquidity and Interbank Markets}

Liquidity risk can be defined as the risk that a bank, though solvent, either does not have enough financial resources to allow it to meet its obligation as they fall due, or can obtain such funds only at excessive costs (Vento and La Ganga, 2009). The bank is able to satisfy the demand for money, and hence is liquid, as long as at each point in time outflows of money are smaller or equal to inflows plus the stock of money held by bank. If outflows are larger than inflows and the stock of money, there is a deficit. The bank has to find a way how to finance it. Depending on the nature, severity and duration of the liquidity 
shock, BIS (2008, p. 20) recommend banks to identify following alternative sources of funding: deposit growth, the lengthening of maturities of liabilities, new issues of short- and long-term debt instruments, intra-group fund transfers, new capital issues, sale of subsidiaries or lines of business, asset securitization, sale of highly liquid assets, drawing-down committed facilities and borrowing from the central bank's marginal lending facilities. Not all of these options may be available in all circumstances and some may be available only with a substantial time delay. However, if the bank is unable to finance the liquidity shortage, the bank will become illiquid and default. Of course, there is also the possibility that the sum of total inflows and the stock of money are larger than outflows. In this case, there is no liquidity risk, no borrowing is necessary and the bank can sell the excess liquidity on the market (Drehman and Nikolau, 2009).

The linkages between banks on the interbank market can destabilize the financial system in periods of higher liquidity risk. At the beginning, there is a liquidity shock: as a result of imperfect market information such as poor solvency of any bank, the liquidity of such bank is threatened. This is the type of idiosyncratic liquidity risk which may not significantly harm the banking sector. The problem arises when the risk is transferred to several financial institutions and becomes a systemic liquidity risk. This can occur through the information channel, the real channel or liquidity hoarding. In case of the information channel, the information contagion means sudden and sometimes also unexpected changes in the behaviour of economic agents which may take the form of herding behaviour, information cascades or even sudden reassessment of economic fundamentals (Komárková et al., 2012). The real channel appears as a direct knock-on effect from illiquid bank to other banks through the financial flows in payment systems or direct linkages between banks (where banks hold assets and liabilities of other banks). A failure of one bank can cause the potential reduction of liquidity stock on interbank market and thus transfer the liquidity shortage to other banks. Especially in periods of higher uncertainty, some illiquid banks may be eliminated from the market. Such banks can then either ask the central bank for liquidity support, or they may try to obtain additional liquidity by selling their assets (Komárková et al., 2012; Geršl and Komárková, 2009).

Liquidity hoarding is a defensive strategy of banks which has systemic effects. Banks with insufficient liquidity can hoard the liquidity by shortening the maturity of its wholesale lending or they can stop rolling over or issuing new wholesale loans completely. Such practice is likely to have adverse systemic consequences by tightening overall funding conditions and cause deterioration in confidence. It can create or deepen liquidity problems of banks which were dependent on these loans. So liquidity hoarding may improve one bank's liquidity position but at the expense of other banks (Kapadia et al., 2012; Acharya and Merrouche, 2013).

As it is evident that bank liquidity is very important and a key characteristics of the global financial crisis was the inaccurate and ineffective liquidity risk management, the Basel Committee issued the Basel III rules. One part of these rules modifies the capital adequacy rules and the second part strengthens the liquidity risk regulation. Basel III rules should prevent the recurrence of crisis situation through these areas of regulation: minimum standards of liquidity (LCR - Liquidity Coverage Ratio and NSFR - Net Stable Funding Ratio) and monitoring tools to assess liquidity risk. The Liquidity Coverage Ratio (LCR) is defined as a share of stock of high-quality liquid assets in total net cash outflows over the next 30 calendar days. The minimum required value of this ratio will be $100 \%$. The LCR 
has been developed to ensure that a bank maintains an adequate level of unencumbered, high-quality liquid assets that can be converted into cash to meet its liquidity needs for a 30-calendar day time horizon under a significantly severe liquidity stress scenario specified by supervisors. By 30 day it is assumed that appropriate corrective actions can be taken by management and/or supervisors, and/or the bank can be resolved in an orderly way. The Net Stable Funding Ratio is defined as the share of available amount of stable funding in required amount of stable funding. The value of this ratio will have to be higher than $100 \%$. The aim of the NSFR is to ensure that long term assets are funded with at least a minimum amount of stable liabilities in relation to their liquidity risk profiles. The NSFR has a time horizon of one year and has been developed to provide a sustainable maturity structure of assets and liabilities. Besides these two ratios, BIS has also developed a set of monitoring tools for assessing liquidity risk, such as contractual maturity mismatch, concentration of funding, available unencumbered assets, Liquidity Coverage Ratio by significant currency, or market-related monitoring tools (BIS, 2010; BIS, 2013). Possible impacts of the Basel III rules are discussed e.g. in Šútorová and Teplý (2013) or Zimková (2010).

\section{Positions of Banks on the Interbank Market in the Visegrad Countries}

We used unconsolidated balance sheet data on annual basis over the period from 2000 to 2011 which were obtained from annual reports of individual banks and from the database BankScope. The data set includes a significant part of each analyzed banking sector, not only by the number of banks but also by their share on total banking assets (Table 1). Due to the homogeneity of the data set, we include only data of commercial banks and we abstract from branches of foreign banks, mortgage banks, building societies and state banks with special purpose (such as Českomoravská záruční a rozvojová banka, Slovenská záručná a rozvojová banka, Česká exportní banka, Exim banka, Magyar Fejlesztési Bank or Bank Gospodarstwa Krajowego).

Activity of banks on the interbank market is reflected in the bank's balance sheet: a loan provided to other bank increases dues from banks on the asset side, a loan drawn from other bank increases dues to banks on the liability side. Comparing dues from banks with dues to banks, we obtain the net position of the bank on the interbank market. If dues from banks are higher than dues to banks, the bank is a net lender on the interbank market. However, if dues to banks are higher than dues from banks, the bank is a net borrower on the interbank market. To be able to compare different-sized banks, we will calculate the share of net interbank position in total assets of the bank (1):

$$
L=\frac{D F B-D T B}{T O A} * 100(\%)
$$

where $L$ is the liquidity ratio, $D F B$ are dues from banks, $D T B$ represents dues to banks and TOA means total assets. The value of this ratio is positive for net lenders and negative for net borrowers. Comparing with clients' deposits, raising funds in the interbank market is significantly more flexible. But due to the low stability of this source of funding (bank is constantly under the control of its counterparties which in case of doubts about the financial situation of the bank may not roll over loans), it is more risky. Banks who are net borrowers are thus much more vulnerable. Median values of the liquidity ratio are presented in Figure 1. 


\begin{tabular}{|c|c|c|c|c|c|c|c|c|c|c|c|c|}
\hline & 00 & 01 & 02 & 03 & 04 & 05 & 06 & 07 & 08 & 09 & 10 & 11 \\
\hline \multicolumn{13}{|c|}{ Czech Republic } \\
\hline $\begin{array}{l}\text { Total number of } \\
\text { banks }\end{array}$ & 40 & 38 & 37 & 35 & 35 & 36 & 37 & 37 & 37 & 39 & 41 & 44 \\
\hline $\begin{array}{l}\text { Number of } \\
\text { observed banks }\end{array}$ & 14 & 15 & 16 & 16 & 16 & 15 & 13 & 13 & 12 & 12 & 13 & 12 \\
\hline $\begin{array}{l}\text { Share in total } \\
\text { assets (\%) }\end{array}$ & 75 & 77 & 76 & 76 & 74 & 71 & 74 & 74 & 68 & 70 & 70 & 77 \\
\hline \multicolumn{13}{|c|}{ Hungary } \\
\hline $\begin{array}{l}\text { Total number of } \\
\text { banks }\end{array}$ & 40 & 41 & 39 & 38 & 35 & 34 & 37 & 38 & 36 & 35 & 35 & 35 \\
\hline $\begin{array}{l}\text { Number of } \\
\text { observed banks }\end{array}$ & 13 & 18 & 23 & 24 & 26 & 29 & 28 & 27 & 25 & 24 & 21 & 13 \\
\hline $\begin{array}{l}\text { Share in total } \\
\text { assets (\%) }\end{array}$ & 72 & 74 & 84 & 86 & 87 & 88 & 88 & 87 & 88 & 88 & 87 & 83 \\
\hline \multicolumn{13}{|c|}{ Poland } \\
\hline $\begin{array}{l}\text { Total number of } \\
\text { banks }\end{array}$ & 73 & 71 & 62 & 60 & 54 & 54 & 51 & 50 & 52 & 49 & 49 & 44 \\
\hline $\begin{array}{l}\text { Number of } \\
\text { observed banks }\end{array}$ & 15 & 24 & 28 & 32 & 34 & 35 & 32 & 31 & 32 & 31 & 27 & 19 \\
\hline $\begin{array}{l}\text { Share in total } \\
\text { assets (\%) }\end{array}$ & 60 & 70 & 73 & 88 & 84 & 84 & 82 & 80 & 79 & 79 & 78 & 74 \\
\hline \multicolumn{13}{|c|}{ Slovakia } \\
\hline $\begin{array}{l}\text { Total number of } \\
\text { banks }\end{array}$ & 23 & 21 & 20 & 21 & 21 & 23 & 24 & 26 & 26 & 26 & 29 & 31 \\
\hline $\begin{array}{l}\text { Number of } \\
\text { observed banks }\end{array}$ & 11 & 13 & 13 & 13 & 13 & 14 & 12 & 12 & 12 & 11 & 10 & 10 \\
\hline $\begin{array}{l}\text { Share in total } \\
\text { assets (\%) }\end{array}$ & 46 & 58 & 54 & 59 & 59 & 65 & 62 & 65 & 69 & 67 & 65 & 66 \\
\hline
\end{tabular}

Source: author's calculations

Only in the Czech banking sector, the median value of this ratio is positive for the whole analyzed period. The Czech banking sector as a whole is a net lender in the interbank market. PPF banka, Equa bank, Komerční banka and GE Money Bank in some years had the highest values of this ratio (and thus they are the biggest net lenders, relatively to their size). Of course, there are some banks that are net borrowers on the interbank market, such as LLBW Bank CZ, Raiffeisenbank and Volksbank. 


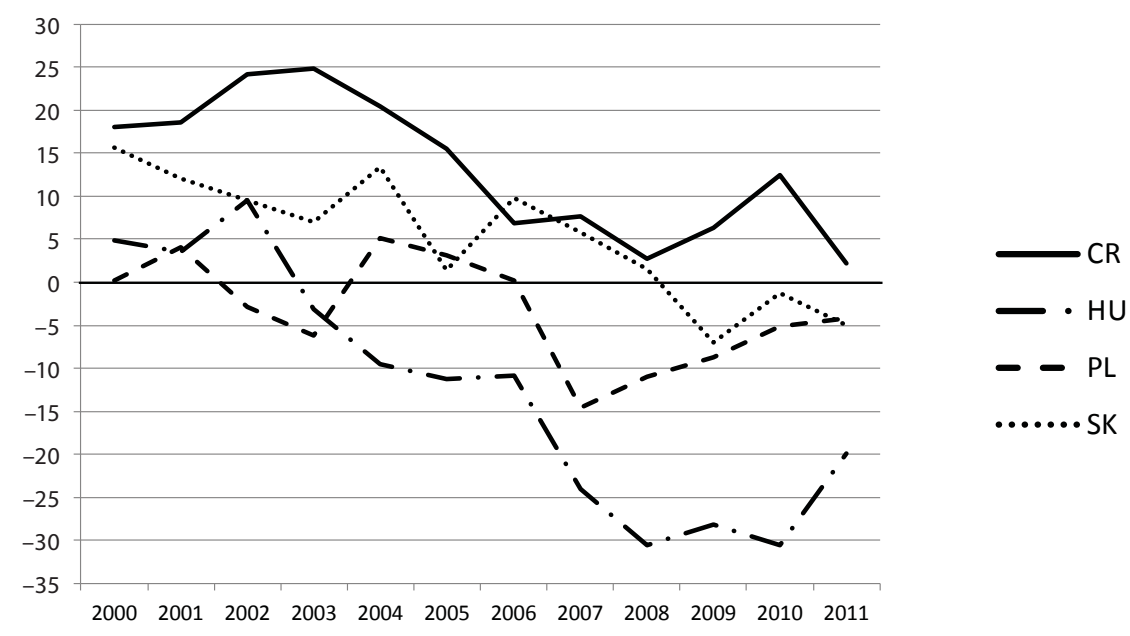

Source: author's calculations

The Slovak banking sector as a whole was a net lender in 2000-2007. In 2008-2011, majority of Slovak banks needed to borrow more funds in interbank market and Slovak banking sector has become net borrower. For the most of the period, Tatra banka, Poštová banka and Slovenská sporitel'ňa belonged to net lenders and Istrobanka, UniCredit Bank and Prima banka were the biggest net borrowers.

The situation in the Hungarian banking sector is even worse: the Hungarian banking sector was a net lender only in 2000-2002. Since 2003, the Hungarian banking sector is a net borrower and mainly in the period 2008-2010, the net interbank position of the Hungarian banking sector was significantly negative (it represented around $30 \%$ of total assets). Magyar Cetelem Bank, TAKAREKBANK and Erste Bank Hungary are significant net borrowers. Only a few banks are net lenders: OTP Bank, Granit Bank, Deutsche Bank and Budapest Bank.

The Polish banking sector is the net borrower almost for the whole analyzed period, with the only exception of 2001. RCI Bank Polska, SGB Bank and Bank BPS are the largest borrowers. However, it is possible to find also banks that are net lenders on the interbank market, such as Bank Pocztowy, Getin Noble Bank, Deutsche Bank Polska or RBS Bank.

In spite of our expectations, the group of Visegrad countries looks quite heterogeneous which is reflected by the significant differences in values of the chosen liquidity ratio. For this reason, it does not make sense to analyse the V4 group as a whole. One can expect that different factors will determine banks' behaviour on the interbank market in different countries. Therefore we will focus only on individual banking sectors.

\section{The Model}

In order to find out determinants which affect the commercial banks' decision to lend on interbank market in the Visegrad countries, we use a probit model. Probit model is a specific form of a panel data regression analysis. In case of the probit model, the dependent variable $L_{i t}$ (i.e. the liquidity ratio for bank $i$ in time $t$ ) can only take two values, i.e. 0 or 1 . 
Suppose that $P_{i}$ denotes probability that $L_{i t}=1$ (i.e. $1-P_{i}$ denotes probability that $L_{i t}=0$ ). The aim is to model the probability $P_{i}$, that the dependent variable will have a value of 1 , specifying the following model (2):

$$
P_{i t}=f\left(\alpha+\beta^{\prime} X_{i t}\right)
$$

where $X_{i t}$ is a vector of explanatory variables (regressors) and $\alpha$ and $\beta^{\prime}$ are estimated parameters. Due to the nonlinear characteristics of this model, the ordinary least square estimate is not possible. It is recommended to use the maximum likelihood method. The estimated values of the coefficients then maximize the value of the dependent variable (Verbeek, 2000).

Two main approaches to the panel data regression analysis are panel data regression analysis with the fixed effects and panel data regression analysis with random effects. The fixed effects model is a linear regression model in which the intercept terms vary over the individual units (Verbeek, 2000). Fixed effects are constant over time. This model is often used in case of panels with macroeconomic variables, where we have a smaller number of units for a longer period of time. Random effects model assumes a specific random component for each cross-sectional unit. This model is typical for panels with microeconomic data, where we have a large number of units for a shorter period of time. It is used also in a situation, where the selection of observed phenomena was made randomly (Lukáčik et al., 2010).

When deciding whether to use fixed or random effects, it is necessary to evaluate whether each variable is randomly selected from a certain group. If this condition is not met, it is necessary to choose the panel data regression analysis with fixed effects (Dougherty, 2002). In addition, it is possible to test panel data using Hausman test (Hausman, 1978), which tests whether the estimation with fixed and random effect are significantly different.

It is evident that the most important task is to choose the appropriate explanatory variables. Although liquidity problems of some banks during the global financial crisis re-emphasized the fact that liquidity is very important for the functioning of financial markets and the banking sector, an important gap still exists in the empirical literature about liquidity and its measuring.

Lucchetta (2007) is the only study that uses the probit model for empirical verification of the hypothesis that interest rates affect banks' risk taking and the decision to hold liquidity across European countries. The analysis is based on data of 5,066 European banks over the period from 1998 to 2004. The study came to conclusion that across European countries, the interbank interest rate positively affects the liquidity retained by banks and the decision of a bank to be a lender on the interbank market. The key variable which affects the decision to lend on the interbank market is the liquidity price which depends on the demand and supply of liquidity and on the risk-free interest rate. The increase of this price increases the liquidity supply and thereby the lending on the interbank market. As this new liquidity is invested by borrowers in risky loans, the rise in the risk-free interest rate increases banks' risk-taking behaviour (which is measured by the share of loans in total assets and share of loan loss provisions in net interest revenues). The results also showed that bank size matters: the lender banks tend to be smaller than borrower ones. The relation between the monetary policy interest rate and the decision of a bank to hold liquidity and to lend on the interbank market is negative.

Due to the lack of any other relevant studies that would cover determinants of bank behaviour on the interbank market, we will also focus on studies that examine the determinants of bank liquidity in the Visegrad countries and in various banking sectors 
around the world. Vodová (2013) analyzed the determinants of the liquid asset ratio in the period from 2000 to 2011 in the Visegrad countries. Both macroeconomic and bank-specific factors were tested. The results of the panel data regression analysis showed that the liquid asset ratio is mostly influenced by the size of the bank, its capital adequacy and profitability. Also overall macroeconomic conditions, such as the growth rate of gross domestic product, the existence of the financial crisis, the exchange rate or the rate of unemployment and the development of interest rates (both on loans and interbank transactions) are important. Other studies analysing determinants of bank liquidity in some countries are e.g. Dinger (2009), Aspachs et al. (2005), Bunda and Desquilbet (2008), Agénor et al. (2000), Moore (2010), Rauch et al. (2011), Fielding and Shortland (2005), Berger a Bouwman (2009), Cornet et al. (2012), Berrospide (2013), Grant (2012) or Munteanu (2012). The review of these studies can be found in Vodová (2013).

Table 2 | Variables Definition

\begin{tabular}{|c|c|c|}
\hline Variable & Description of variable & Source \\
\hline $\mathbf{L}$ & dependent variable: 1 for net lenders and 0 for net borrowers & $\begin{array}{l}\text { annual reports, } \\
\text { BankScope }\end{array}$ \\
\hline LIA & share of liquid assets in total assets & $\begin{array}{l}\text { annual reports, } \\
\text { BankScope }\end{array}$ \\
\hline LOA & share of loans in total assets & $\begin{array}{l}\text { annual reports, } \\
\text { BankScope }\end{array}$ \\
\hline CAP & capital adequacy: share of capital in total liabilities & $\begin{array}{l}\text { annual reports, } \\
\text { BankScope }\end{array}$ \\
\hline NPL & $\begin{array}{l}\text { share of classified loans (substandard, watch and loss) in total } \\
\text { loans }\end{array}$ & $\begin{array}{l}\text { annual reports, } \\
\text { BankScope }\end{array}$ \\
\hline ROE & return on equity: share of net profit in bank's capital & $\begin{array}{l}\text { annual reports, } \\
\text { BankScope }\end{array}$ \\
\hline TOA & size of the bank: logarithm of total assets & $\begin{array}{l}\text { annual reports, } \\
\text { BankScope }\end{array}$ \\
\hline FIC & $\begin{array}{l}\text { dummy variable for financial crisis ( } 1 \text { in } 2009,0 \text { in rest of the } \\
\text { period for CR and SK, } 1 \text { in } 2008 \text { and } 2009,0 \text { in rest of the period } \\
\text { for PL and HU) }\end{array}$ & own \\
\hline GDP & growth rate of gross domestic product: GDP volume \% change & IMF \\
\hline INF & inflation rate: consumer price index $\%$ change & IMF \\
\hline IRB & interest rate on interbank transactions & IMF \\
\hline IRL & interest rate on loans & IMF \\
\hline IRM & $\begin{array}{l}\text { interest margin: difference between interest rate on loans and } \\
\text { interest rate on deposits }\end{array}$ & IMF \\
\hline MIR & monetary policy interest rate & IMF \\
\hline UNE & unemployment rate & IMF \\
\hline EUR & exchange rate CZK(HUF, PLN)/EUR (yearly average) & Oanda \\
\hline
\end{tabular}

Source: author's calculations 
The selection of variables was based on the above cited relevant studies. For each variable, we considered whether its use makes economic sense in the Visegrad countries. For this reason, we excluded from the analysis variables such as political incidents. We also considered which other factors could influence the bank liquidity. The limiting factor then was the availability of some data. Table 2 provides a precise definition of used variables, together with the data source.

We considered six bank specific factors (share of liquid assets in total assets, share of loans in total assets, capital adequacy, share of classified loans in total loans, return on equity and size of the bank) and nine macroeconomic factors. We do not have an exact expectation of the impact of these factors on the bank liquidity because their impact was different in the above cited studies. The macroeconomic data were provided by the International Financial Statistics of the International Monetary Fund (IMF). The data on average exchange rates $^{1}$ were provided by Oanda database. The bank specific data were calculated from the data published in the annual reports of individual banks or from the BankScope database.

\section{Results and Discussion}

Before the regression analysis, it is necessary to carry out the unit root tests of the time series used. For this purpose, we used the Levin, Lin, Chu test which indicated that all time series are stationary on their level. We performed the unit root tests for panels of the tested banking sectors. Because of the stationarity of time series, we could continue with the probit model. We have also applied the Durbin-Wu-Hausman test which showed that for our collected panel data, we should choose the panel data regression analysis with fixed effects, where the cross-sectional effects are fixed and the time effects are none.

First we included all explanatory variables which might have an effect on the dependent variable: we estimated the Equation (2), which has the following initial form (3):

$$
\begin{gathered}
P_{i t}=f\left(\alpha+\beta_{1} C A P_{i t}+\beta_{2} N P L_{i t}+\beta_{3} R O E_{i t}+\beta_{4} T O A_{i t}+\beta_{5} F I C_{i t}+\beta_{6} G D P_{i t}+\beta_{7} I N F_{i t}+\right. \\
\left.+\beta_{8} I R B_{i t}+\beta_{9} I R L_{i t}+\beta_{10} I R M_{i t}+\beta_{11} M_{I t}+R_{i t}+\beta_{12} U N E_{i t}+\beta_{13} E U R_{i t}+\beta_{14} L I A_{i t}+\beta_{15} L O A_{i t}\right)
\end{gathered}
$$

where $L_{i t}$ is 1 for the bank which is a net lender and 0 for the bank which is a net borrower on the interbank market in the given year. The probability that the bank will be a net lender is affected by variables specified above, $\alpha$ is a constant for the whole regression model, $\beta$ are the estimated parameters.

To reduce the number of explanatory variables, we used the results of diagnostic tests determining the redundancy of variables. We also took into account the information criteria, including Akaike criterion, Schwarz criterion and Hannan-Quinn criterion. We also considered the correlation and statistical significance of individual variables. Our aim is to find a regression model with a high value of the adjusted coefficient of determination in which all the variables involved are statistically significant. The results of these final models are presented in following tables.

1 It is evident from Table 2 that the variable EUR does not consider the development of the exchange rate SKK/EUR. The reason is that the euro is the official currency in Slovakia from 1 January 2009. We wanted to assess whether the development of the exchange rate SKK/EUR had any impact on liquidity of Slovak banks by the year 2008, therefore we tried to estimate equation 3.3 only for the period 2000-2008. However, the exchange rate was not statistically significant. This is the reason why we do not use this variable in regression models for Slovak banks and we present only results for the whole analysed period, i.e. 2000-2011. 
As it can be seen from Table 3, net lenders are rather banks with higher liquidity and higher capital adequacy in the Czech Republic. Their decision to provide interbank loans is influenced also by the growth rate of gross domestic product and signs of financial crisis in the Czech banking sector.

Czech net lenders maintain a higher buffer of liquid assets (the ratio LIA) than net borrowers, i.e. the probability that the bank will be a net lender increases with higher liquidity of that bank. Such result is not surprising. Dues from banks represents a significant part of liquid assets, thereby themselves increases the bank liquidity.

The probability that the bank will be net lender increases also with higher capital adequacy. Again, this is not a surprising finding: according to our findings, Czech banks with higher capital adequacy are more liquid and more liquid banks can provide more loans to other banks. This confirms again the risk absorption hypothesis (see Vodová, 2013).

Table 3 | Determinants of Net Lenders on the Interbank Market in the Czech Republic

\begin{tabular}{|l|c|c|}
\hline Variable & Coefficient & Standard deviation \\
\hline Constant $\mathbf{a}$ & $-11.6749^{*}$ & 2.16505 \\
\hline CAP & $0.08825^{*}$ & 0.02839 \\
\hline FIC & $-1.68957^{* * *}$ & 0.89758 \\
\hline GDP & $0.18121^{* *}$ & 0.09103 \\
\hline LIA & $0.08878^{*}$ & 0.01558 \\
\hline Pseudo (McFadden) R & \multicolumn{2}{|c|}{0.425041} \\
\hline Total observations & \multicolumn{2}{|c|}{167} \\
\hline
\end{tabular}

Note: The starred coefficient estimates are significant at the $1 \%\left({ }^{*}\right), 5 \%\left({ }^{* *}\right)$ or $10 \%\left({ }^{* *}\right)$ level. Source: author's calculations

As the coefficient of financial crisis is the highest, it seems that financial crisis influenced the banks' behaviour on the interbank market really significantly. As it can be seen from the Table 3, the probability that Czech banks will be net lenders declined during financial crisis. This is clear evidence that at least some Czech banks hoarded liquidity in response to the financial crisis, i.e. they tried to shorten the maturity of interbank loans or reduce volume of these loans.

This is confirmed also by the sign of the regression coefficient of the last statistically significant variable: the higher the growth rate of gross domestic product, the higher is the probability that banks will be net lenders. During recession, banks are likely more cautious and prefer other forms of liquid assets, such as government securities or balances with central bank. Conversely, during expansion, banks perceive credit risk of other banks as lower, therefore their willingness to provide interbank loans increases.

Determinants of net lenders on the interbank market for Hungarian banks are presented in Table 4. Four variables are statistically significant: the interbank interest rate, the interest margin, the share of loans in total assets and the unemployment rate. 
Table 4 | Determinants of Net Lenders on the Interbank Market in Hungary

\begin{tabular}{|l|c|c|}
\hline Variable & Coefficient & Standard deviation \\
\hline Constant a & $3.42015^{*}$ & 1.29668 \\
\hline IRB & $-0.27497^{* *}$ & 0.10920 \\
\hline IRM & $0.25205^{*}$ & 0.09363 \\
\hline LOA & $-0.02713^{*}$ & 0.00383 \\
\hline UNE & $-0.36643^{*}$ & 0.10975 \\
\hline Pseudo (McFadden) R & \multicolumn{2}{|c|}{0.232571} \\
\hline Total observations & \multicolumn{2}{|c|}{260} \\
\hline
\end{tabular}

Note: The starred coefficient estimates are significant at the $1 \%\left(^{*}\right), 5 \%\left({ }^{* *}\right)$ or $10 \%(* * *)$ level. Source: Author's calculations

The behaviour of Hungarian banks on the interbank market is affected by the interbank interest rate and the interest margin. In case of the interbank interest rate, we came to the opposite conclusion than Lucchetta (2007): the increase of interbank interest rate lowers the motivation of Hungarian banks to provide interbank loans, i.e. the probability that Hungarian banks will be net lenders, is decreasing. Hungarian banks unambiguously perceive a higher interest rate as a signal of higher credit risk. Therefore, even though they could potentially achieve higher profits at higher interest rates, they are not willing to provide such loans because they recognize the likelihood of the deterioration of the loan portfolio and its negative impact on bank profitability. Instead, they prefer to focus on other items of liquid assets, particular on government securities. Such behaviour is fully consistent with the problem of credit crunch and credit rationing. Not only Hungarian but some Eurozone banks acted in this manner as well. However, such behaviour, together with high level of their interconnectedness to sovereigns, was an important cause of the troubles on the interbank market.

This finding is fully supported also by the positive sign of the regression coefficient for the interest margin. This means that the increase in the interest margin is for Hungarian banks again a signal of higher credit risk, but this time the risk is associated with loans to non-bank customers. Because banks do not want to accept this risk, they prefer less risky operations such as lending in the interbank market. The increase in the interest margin thus increases the probability that Hungarian banks become net lenders in the interbank market.

The results of the probit model estimation further confirm the link between the net interbank position and the lending activity of the bank. It is logical that banks with a higher share of loans to non-bank clients in total assets (i.e. with higher ratio LOA) cannot focus so much on lending to other banks. At the same time, banks with lower value of the ratio LOA can provide more interbank loans. Therefore the probability that the bank will be a net lender decreases with higher share of loans in total assets.

The unemployment rate is the last statistically significant variable. It may also express in some way the link between lending activity to bank and non-bank borrowers. With rising unemployment rate, the demand for loans is increasing. Meeting this demand decreases 
bank liquidity. Banks therefore do not have the excess liquidity so they can provide less interbank loans. The rise in unemployment rate therefore decreases the likelihood that Hungarian banks will be net lenders in the interbank market.

Table 5 | Determinants of Net Lenders on the Interbank Market in Poland

\begin{tabular}{|l|c|c|}
\hline Variable & Coefficient & Standard deviation \\
\hline Constant a & $-2.92576^{*}$ & 0.66831 \\
\hline CAP & $-0.04442^{*}$ & 0.013455 \\
\hline IRB & $0.15439^{*}$ & 0.04941 \\
\hline LIA & $0.03015^{*}$ & 0.00478 \\
\hline NPL & $0.02943^{*}$ & 0.00935 \\
\hline Pseudo (McFadden) R & & \\
\hline Total observation & \multicolumn{2}{|c|}{0.20980} \\
\hline
\end{tabular}

Note: The starred coefficient estimates are significant at the $1 \%\left({ }^{*}\right), 5 \%\left({ }^{* *}\right)$ or $10 \%\left({ }^{* *}\right)$ level.

Source: Author's calculations

The net interbank position in Poland is determined also by four variables: the share of liquid assets in total assets, the interbank interest rate, the capital adequacy and the quality of loan portfolio. Again, first we included all explanatory variables which might have an effect on the dependent variable and then we reduced them with the use of information criteria to the final model (Table 5).

The impact of the share of liquid assets in total assets, i.e. the ratio LIA, is the same as in case of Czech banks. Polish banks which are net lenders also have higher liquidity than net borrowers (the difference between the share of liquid assets in total assets for net lenders and net borrowers is more than 20 percentage points in some years).

In contrast, unlike in the Czech Republic, the probability that Polish banks will be net lenders decreases with the increase of the capital adequacy. However, this finding is entirely consistent with our conclusion from the panel data regression analysis for the ratio LIA (see Vodová, 2013): again, the financial fragility-crowding out hypothesis is confirmed (this hypothesis suggests that banks with higher capital adequacy monitor their borrowers less carefully - see Berger and Bouwman, 2009).

The effect of the interbank interest rate is opposite than for Hungarian banks. This means that the interbank interest rate can be perceived as the price of liquidity obtained on the interbank market. The increase of this price is a clear motive for lender banks to raise their supply of liquidity on the interbank market because higher interbank interest rate makes these transactions more profitable. Therefore the higher the interbank interest rate, the higher the probability that Polish banks will become net lenders. This is the same conclusion as in Lucchetta (2007).

The decision of banks about their net interbank position is influenced also by the quality of their loan portfolio. Polish banks react cautiously on the deterioration of the loan portfolio by limiting the lending activity to non-bank borrowers. Banks can invest these 
released funds on the interbank market. The probability that Polish banks will be net lenders increases with the growth of the share of classified loans in total loans.

Finally, Slovak net lenders have a lower share of loans in total assets and their decision is influenced also by the growth rate of gross domestic product and the interest rate on loans (Table 6).

Table 6 | Determinants of Net Lenders on the Interbank Market in Slovakia

\begin{tabular}{|l|c|c|}
\hline Variable & Coefficient & Standard deviation \\
\hline Constant $\boldsymbol{\alpha}$ & $4.93678^{*}$ & 0.96736 \\
\hline GDP & $0.08456^{* *}$ & 0.03597 \\
\hline IRL & $0.05080^{* * *}$ & 0.04003 \\
\hline LOA & $-0.03291^{*}$ & 0.00893 \\
\hline Pseudo (McFadden) $\mathbf{R}^{\mathbf{2}}$ & \multicolumn{2}{|c|}{0.184192} \\
\hline Total observation & \multicolumn{2}{|c|}{132} \\
\hline
\end{tabular}

Note: The starred coefficient estimates are significant at the $1 \%\left(^{*}\right), 5 \%\left({ }^{* *}\right)$ or $10 \%(* *)$ level.

Source: Author's calculations

The decision of Slovak banks to provide interbank loans depend on the business cycle. Banks are less willing to provide interbank loans during recession because they prefer to meet the increased demand for loans by households and companies. Conversely, companies and households repay loans during expansion, which increases bank liquidity. The excess liquidity can be then invested in the interbank market. This is the same effect as we have identified for Czech banks.

The positive impact of the interest rate on loans on the probability that Slovak banks will be net lenders on the interbank market fully corresponds with our results for the determinants of liquidity (Vodová, 2013). In the Slovak banking sector, banks perceive a higher interest rate on loans as a signal of higher credit risk which stimulates them to reduce lending to households and companies and to prefer interbank market activities.

The influence of the last variable is the same as for Hungarian banks. In principle, also Slovak banks can either focus on loans to non-bank borrowers or on interbank loans. The probability that the bank will be a net lender thus decreases with increasing value of the ratio LOA, i.e. the share of loans in total assets.

\section{Conclusion}

The aim of this paper was to find out determinants which affect the commercial banks' decisions to lend on the interbank market in the Visegrad countries.

First we have focused on the activity of banks on the interbank market. The Czech banking sector as a whole is a net lender for the whole analysed period, the Slovak banking sector in period 2000-2007. The Hungarian banking sector is a net borrower since 2003. The Polish banking sector is the most vulnerable; it was a net lender only in 2001. 
We have used probit model for identification of factors which determines the position of banks in the interbank market. The results showed that net lenders are more liquid in all Visegrad countries, irrespective of whether bank liquidity is measured by the share of liquid assets in total assets (in the Czech Republic and Poland) or by the share of loans in total assets (in Hungary and Slovakia). Capital adequacy also matters: Czech net lenders have higher capital adequacy, while Polish net lenders lower. The last bank specific factor which affects the net interbank position is the quality of the loan portfolio: with the deterioration of this quality, Polish banks start to focus more on interbank activities which increases the probability that they will be net lenders. Also several macroeconomic factors are important. Czech and Slovak banks are more willing to provide interbank loans during expansions. During the financial crisis, Czech banks even started to hoard liquidity. Hungarian banks react on the development of the unemployment rate: with the increase of this rate, they provide more loans to non-bank clients, which decrease the probability that they will be net lenders on the interbank market. Also interest rates play an important role. Slovak banks perceive the increase of interest rate on loans as a signal of a higher credit risk of the borrower and thus they shift their activities towards the interbank market. Hungarian banks react similarly to an increase in interest margin; moreover, they provide more interbank loans during periods of low interbank interest rates. On the contrary, activity of Polish banks on the interbank market grows with the increase of interbank interest rate. Return on equity, size of the bank, inflation rate, exchange rate development and monetary policy interest rate have no effect on the net interbank position in any of the analyzed countries.

There are many ways which may improve the research about determinants affecting the commercial banks' decisions to lend on the interbank market in the future. First, we can simply extend the time series and divide the analysis into pre-crisis, crisis and post-crisis periods. Another possibility is to extend the research into other banking sectors, e.g. to include other Central and Eastern European countries. It would be also possible to include other variables which may have effect on bank behaviour on the interbank market (such as Liquidity Coverage Ratio or Net Stable Funding Ratio).

\section{References}

Acharya, V. V., Merrouche, O. (2013), "Precautionary Hoarding of Liquidity and Interbank Markets: Evidence from the Subprime Crisis." Review of Finance, Vol. 17, No. 1, pp. 107-160.

Agénor, P., Aizeman, J., Hoffmaister, A. (2000), "The Credit Crunch in East Asia: What Can Bank Excess Liquid Assets Tell Us?" National Bureau of Economic Research Working Paper No. 7951.

Allen, F., Gale, D. (2000), "Financial Contagion." Journal of Political Economy, Vol. 108, No. 1, pp. 1-33.

Aspachs, O., Nier, E., Tiesset, M. (2005), “Liquidity, Banking Regulation and the Macroeconomy. Evidence on Bank Liquidity Holdings from a Panel of UK-Resident Banks." Bank of England Working Paper.

Barrell, R., Davis, E. P., Fic, T., Holland, D., Kirby, S., Liadze, I. (2009), “Optimal Regulation of Bank Capital and Liquidity: How to Calibrate New International Standards." Financial Service Authority Occasional Paper No. 38.

Berger, A. N., Bouwman, C. H. S. (2009), "Bank Liquidity Creation." Review of Financial Studies, Vol. 22, No. 9, pp. 3779-3837. 
Berrospide, J. (2013), "Bank Liquidity Hoarding and the Financial Crisis: An Empirical Evaluation." Finance and Economics Discussion Series of Federal Reserve Board, 03.

BIS (2008), "Principles for Sound Liquidity Risk Management and Supervision." Basel: Bank for International Settlements.

BIS (2009), “International Framework for Liquidity Risk Measurement, Standards and Monitoring." Basel: Bank for International Settlements.

BIS (2010), “Basel III: International Framework for Liquidity Risk Measurement, Standards and Monitoring." Basel: Bank for International Settlements.

BIS (2013), "Basel III: The Liquidity Coverage Ratio and Liquidity Risk Monitoring Tools." Basel: Bank for International Settlements.

Blavarg, M., Nimander, P. (2002), "Interbank Exposures and Systemic Risk." Sveriges Riksbank Economic Review, No. 2, pp. 19-45.

Bunda, I., Desquilbet, J. B. (2008), "The Bank Liquidity Smile Across Exchange Rate Regimes." International Economic Journal, Vol. 22, No. 3, pp. 361-386.

Cornet, M. M., McNutt, J. J., Strahan, P. E., Tehranian, H. (2012), “Liquidity Risk Management and Credit Supply in the Financial Crisis." Journal of Financial Economics, Vol. 101, No. 2, pp. 297-312.

Černohorská, L., Teplý, P., Vrábel, M. (2012), “The VT Index as an Indicator of Market Liquidity Risk in Slovakia." Journal of Economics, Vol. 60, No. 3, pp. 223-238.

Černohorský, J., Teplý, P., Vrábel, M. (2010), “Liquidity Market Support During the Global Crisis." Scientific Papers of the University Pardubice, Vol. 17, No. 2, pp. 39-49.

Dinger, V. (2009), “Do Foreign-Owned Banks Affect Banking System Liquidity Risk?” Journal of Comparative Economics, Vol. 37, No. 4, pp. 647-657.

Dougherty, C. (2006), Introduction to Econometrics. Oxford: Oxford University Press.

Drehman, M., Nikolau, K. (2009), "Funding Liquidity Risk. Definition and Measurement." European Central Bank Working Paper Series No. 1024.

Ewerhart, C., Valla, N. (2008), "Financial Market Liquidity and the Lender of Last Resort," in Banque de France Financial Stability Review. Paris: Banque de France, pp. 133-148.

Fielding, D., Shortland, A. (2005), "Political Violence and Excess Liquidity in Egypt." Journal of Development Studies, Vol. 41, No. 4, pp. 542-557.

Geršl, A., Komárková, Z. (2009), “'Liquidity Risk and Banks' Bidding Behaviour: Evidence from the Global Financial Crisis." Czech Journal of Economics and Finance, Vol. 59, No. 6, pp. 577-592.

Grant, J. (2012), “Liquidity Buffers of Australian-Owned ADIs." JASSA, Vol. 2012, No. 3, pp. 31-36.

Hausman, J. A. (1978), "Specification Tests in Econometrics." Econometrica, Vol. 46, No. 6, pp. $1251-1271$.

Kapadia, S., Drehmann, M., Elliot, J., Sterne, G. (2012), “Liquidity Risk, Cash-Flow Constraints and Systemic Feedbacks." Bank of England Working Paper No. 456.

Klinger, T., Teplý, P. (2013), "Systemic Risk of the Global Banking System - an Agent-Based Network Model Approach." Prague Economic Papers, Vol. 23, No. 1, pp. 24-41, http://dx.doi.org/10.18267/j.pep.471

Komárková, Z., Komárek, L., Jakubík, P. (2012), Zranitelnost českého bankovního sektoru. Studie národohospodárského ústavu Josefa Hlávky č. 10. Prague: Národohospodářský ústav Josefa Hlávky. 
Lawson, C. W., Zimková, E. (2009), "The Credit Crisis: What Lessons for Visegrad?" Prague Economic Papers, Vol. XVIII, No. 2, pp. 99-114, , http://dx.doi.org/10.18267/j.pep.344

Lucchetta, M. (2007), "What Do Data Say about Monetary Policy, Bank Liquidity and Bank Risk Taking?" Economic Notes by Banca Monte dei Paschi di Siena SpA, Vol. 36, No. 2, pp. 189-203.

Lukáčik, M., Lukáčiková, A., Szomolányi, K. (2010), Panelové data v programe EViews. Bratislava: EUBA.

Matoušek, R., Stavárek, D. (2012), Financial Integration in the European Union. Abingdon, Oxon: Routledge.

Memmel, C., Sachs, A. (2013), "Contagion in the Interbank Market and Its Determinants", Journal of Financial Stability, Vol. 9, No. 1, pp. 46-54, http://dx.doi.org/10.1016/ j.jfs.2013.01.001

Moore, W. (2010), “How Do Financial Crises Affect Commercial Bank Liquidity? Evidence from Latin America and the Caribbean." Munich Personal RePEc Archive Paper No. 21473.

Munteanu, I. (2012), "Bank Liquidity and Its Determinants in Romania." Procedia Economics and Finance, No. 3, pp. 993-998, http://dx.doi.org/10.1016/S2212-5671(12)00263-8

Rauch, C., Steffen, S., Hackethal, A., Tyrell, M. (2010), “Determinants of Bank Liquidity Creation." Available at: http://papers.ssrn.com/sol3/papers.cfm?abstract_id=1343595.

Řepková, I., Stavárek, D. (2011), "Banking Competition in the Czech Republic, Slovakia and Poland," in Proceedings of the 10th International Conference Liberec Economic Forum 2011. Liberec: Technical University, pp. 402-410.

Stavárek, D. (2010), "Exchange Market Pressure and de facto Exchange Rate Regime in the Euro-Candidates." Romanian Journal of Economic Forecasting, Vol. 13, No. 2, pp. 119-139.

Stavárek, D., Heryán, T. (2012), "Day of the Week Effect in Central European Stock Markets." E+M Ekonomie a Management, Vol. 15, No. 4, pp. 134-146.

Šútorová, B., Teplý, P. (2013), "The Impact of Basel III on Lending Rates of EU Banks." Finance a Úvěr, Vol. 60, No. 3, pp. 226-243.

Teplý, P., Vrábel, M., Černohorská, L. (2012), "The VT Index as an Indicator of Market Liquidity Risk in Slovakia." Ekonomický časopis, Vol. 60, No. 3, pp. 223-238.

Vento, G. A., La Ganga, P. (2009), "Bank Liquidity Risk Management and Supervision: Which Lessons from Recent Market Turmoil?" Journal of Money, Investment and Banking, No. 10, pp. 79-126.

Verbeek, M. (2004), A Guide to Modern Econometrics. $2^{\text {nd }}$ Edition. Chichester: John Wiley and Sons.

Vodová, P. (2012), “Price Indicators as a Measure of Credit Market Integration in the Visegrad Countries." Romanian Journal of Economic Forecasting, Vol. 15, No. 1, pp. 62-73.

Vodová, P. (2013), "Liquid Assets in Banking: What Matters in the Visegrad Countries?" E+M Ekonomie a Management, Vol. 16, No. 3, pp. 113-129.

Wells, S. (2004), "Financial Interlinkages in the United Kingdom's Interbank Market and the Risk of Contagion." Bank of England Working Paper No. 230.

Zimková, E. (2010), “Vplyv Basel III na reguláciu bánk." Acta Aerarii Publici, Vol. 7, No. 2, pp. 89-100. 